\title{
Targeting the Prodromal Stage of Alzheimer's Disease: Bioenergetic and Mitochondrial Opportunities
}

\author{
Charles C. Caldwell • Jia Yao • Roberta Diaz Brinton
}

Published online: 23 December 2014

(C) The American Society for Experimental NeuroTherapeutics, Inc. 2014

\begin{abstract}
Alzheimer's disease (AD) has a complex and progressive neurodegenerative phenotype, with hypometabolism and impaired mitochondrial bioenergetics among the earliest pathogenic events. Bioenergetic deficits are well documented in preclinical models of mammalian aging and $\mathrm{AD}$, emerge early in the prodromal phase of $\mathrm{AD}$, and in those at risk for AD. This review discusses the importance of early therapeutic intervention during the prodromal stage that precedes irreversible degeneration in AD. Mechanisms of action for current mitochondrial and bioenergetic therapeutics for AD broadly fall into the following categories: 1) glucose metabolism and substrate supply; 2) mitochondrial enhancers to potentiate energy production; 3) antioxidants to scavenge reactive oxygen species and reduce oxidative damage; 4 ) candidates that target apoptotic and mitophagy pathways to either remove damaged mitochondria or prevent neuronal death. Thus far, mitochondrial therapeutic strategies have shown promise at the preclinical stage but have had little-to-no success in clinical trials. Lessons learned from preclinical and clinical therapeutic studies are discussed. Understanding the bioenergetic adaptations that occur during aging and $\mathrm{AD}$ led us to focus on a systems biology approach that targets the bioenergetic system rather than a single component of this system.
\end{abstract}

\footnotetext{
C. C. Caldwell

Clinical and Experimental Therapeutics Program, School of Pharmacy, University of Southern California, Los Angeles, CA 90089, USA

J. Yao $\cdot$ R. D. Brinton $(\bowtie)$

Department of Pharmacology and Pharmaceutical Sciences, School of Pharmacy, University of Southern California, Los Angeles, CA 90089, USA

e-mail: rbrinton@usc.edu

R. D. Brinton

Department of Neurology, Keck School of Medicine, University of Southern California, Los Angeles, CA 90089, USA
}

Bioenergetic system-level therapeutics personalized to bioenergetic phenotype would target bioenergetic deficits across the prodromal and clinical stages to prevent and delay progression of $\mathrm{AD}$.

Key Words Alzheimer's disease (AD) mitochondria · prodromal $\cdot$ therapeutics $\cdot$ neurodegeneration $\cdot$ bioenergetics

\section{Introduction}

Alzheimer's disease $(\mathrm{AD})$ remains without an effective strategy to prevent, delay, or treat the disease. In 2010, the World Health Organization estimated the number of persons with AD-related dementia at 35.6 million, which is expected to triple by 2050 to over 115 million [1]. The projected number of persons with $\mathrm{AD}$ in the USA by 2050 is 13.5 million, and the medical costs will exceed $\$ 20$ trillion over the next 40 years $[2,3]$. The measurable socioeconomic annual costs of the disease on a global scale were estimated to exceed $\$ 600$ billion in 2010 [1, 4]. Socioeconomic data predict that significant decreases in medical costs are possible if therapeutic development shifts to identification and prevention of $\mathrm{AD}$ rather than attempts to reverse AD pathology [5].

Since 1998, there have been 101 failed Alzheimer's trials [6]. Currently available drugs offer moderate symptom alleviation [6]. No therapeutic strategies have demonstrated clinically significant disease-modifying benefits to halt or reverse cognitive decline. Most of the therapeutic candidates have focused on reduction or reversal of AD pathology based on the $\beta$-amyloid $(A \beta)$ plaque hypothesis. Several antiamyloid drug candidates have failed in late-stage clinical trials $[4,7]$. Despite preclinical success in cell lines and animal models, most therapeutic candidates for $\mathrm{AD}$ failed to show any significant effect on cognitive function at clinical stages [6]. These 
failures can be attributed to multiple factors that arise during drug development in both preclinical and clinical settings.

As multifactorial diseases present differently, responses to therapies also differ. For example, unhealthy diet and exercise may have different impacts on individuals and require different treatment strategies than those individuals predisposed to genetically inherited familial diseases [8]. Sex, genetic risks, and age are important variables that should be considered during the development stage for $\mathrm{AD}$ therapeutics $[9,10]$. The dosing regimen, formulation, and the route of administration all have significant effects on clinical success [10]. Past approaches targeting moderate and severe AD pathology have had minimal success, in part because of the single target strategy for a multifactorial pathology. In contrast, targeting the affected biological systems at specific stages of disease progression may have greater likelihood of success in nonfamilial AD.

The presymptomatic and prodromal stages of $\mathrm{AD}$ are windows of opportunity likely to have the greatest impact on reducing the risk and incidence of $\mathrm{AD}$ (Fig. 1). Dysfunctions in glucose metabolism, bioenergetics, and mitochondrial function are consistent antecedents leading to $\mathrm{AD}$ pathology, including $A \beta$ plaque and neurofibrillary tangles [11]. Dysfunctional mitochondria produce high levels of reactive oxygen species (ROS); these ROS can negatively affect specific mitochondrial components, including mitochondrial DNA (mtDNA), membrane lipids, and oxidative phosphorylation proteins $[18,19]$. For example dysregulation of complex I has been correlated with tau toxicity, and dysregulation of complex IV has been associated with increased $A \beta$ load [20-22]. Additionally, specific proteins are affected by mitochondrial dysfunction in $\mathrm{AD}$, including amyloid precursor protein, presenilin 1 and presenilin 2, which reside along the mitochondria-associated endoplasmic reticulum membranes [23]. Decline in glucose metabolism and mitochondrial function are detected decades prior to clinical features of the disease making them potential biomarkers and therapeutic targets for prevention $[12,13,24]$. In vitro and in vivo preclinical AD models indicate that deficits in mitochondrial function, metabolic enzyme expression and activity, cerebral glucose metabolism, and free radical scavenging are coupled with mitochondrial $A \beta$ load and $A \beta$-binding alcohol dehydrogenase (ABAD) expression [12, 13, 24, 25]. Importantly, clinical studies indicate that mitochondrial deficits observed in preclinical models are evident in human-derived platelets [14, 15, 26-29]. The antecedent decline in mitochondrial function and brain metabolism indicates an early and potentially causal role in $\mathrm{AD}$ pathogenesis. Thus, targeting mitochondria and brain bioenergetics could be a disease-modifying strategy to prevent and/or delay the progression of $\mathrm{AD}$. Targeting brain metabolism and mitochondrial function are relevant to the hypometabolism and impaired mitochondrial bioenergetics that are among the earliest pathogenic events.

\section{Current Strategies Targeting Mitochondria and Bioenergetics in AD}

The integrity and viability of the bioenergetic system is a fundamental determinant of synaptic and brain function $[9$, $30-32]$. Although the human brain accounts for $2 \%$ of the body's mass, it consumes $20 \%$ of the body's fuel supply for
Fig. 1 The five stages of Alzheimer's disease (AD) pathology and 3 therapeutic treatment windows. The prodromal stage encompasses the presymptomatic and mild cognitive impairment stages of $\mathrm{AD}$. White line = progression of cognitive decline through the 5 stages of AD [11-17]. FDG$\mathrm{PET}=$ fluoro-2-deoxyglucose positron emission tomography; MRI, magnetic resonance imaging

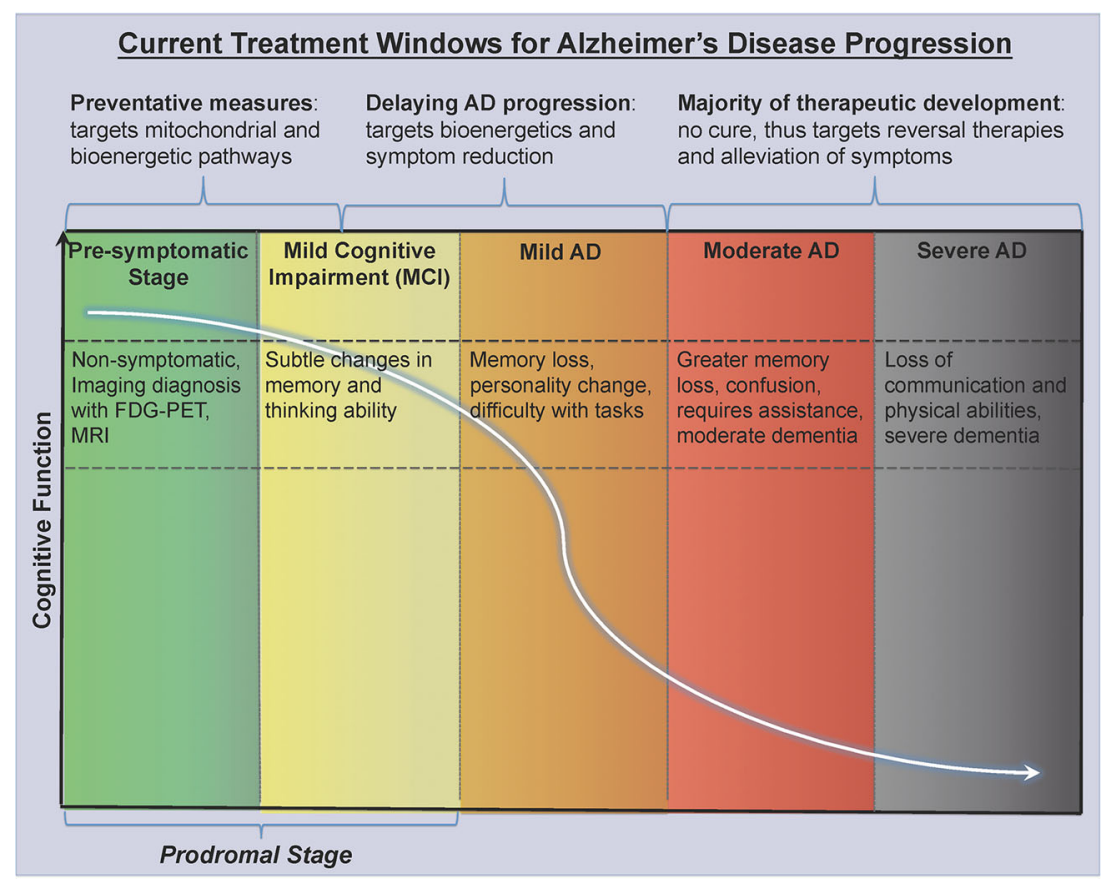


adenosine triphosphate (ATP) production [9]. The bioenergetic system consists of obligatory processes that are tightly coupled, including substrate supply, transporters, and the catalytic machineries required for oxidative phosphorylation and ATP generation (Fig. 2). Compromised brain metabolism is an early indicator of $\mathrm{AD}$ in both preclinical and clinical investigations [31]. Previous studies have suggested that a decrease in brain bioenergetics may be a useful biomarker to predict disease decades before symptoms [33-36]. Decreases in mitochondrial bioenergetics, metabolic enzyme expression and activity, cerebral glucose metabolism, along with increased oxidative stress, $A \beta$ deposits within mitochondria, and expression of $\mathrm{ABAD}$ are associated with the prodromal state of $\mathrm{AD}[34,37-42]$.

Glucose Uptake and Substrate Supply as Therapeutic Targets

Decreased glucose metabolism is an early hallmark of the prodromal AD stage [43]. Brain hypometabolism and deficits in mitochondrial bioenergetics have long been documented in

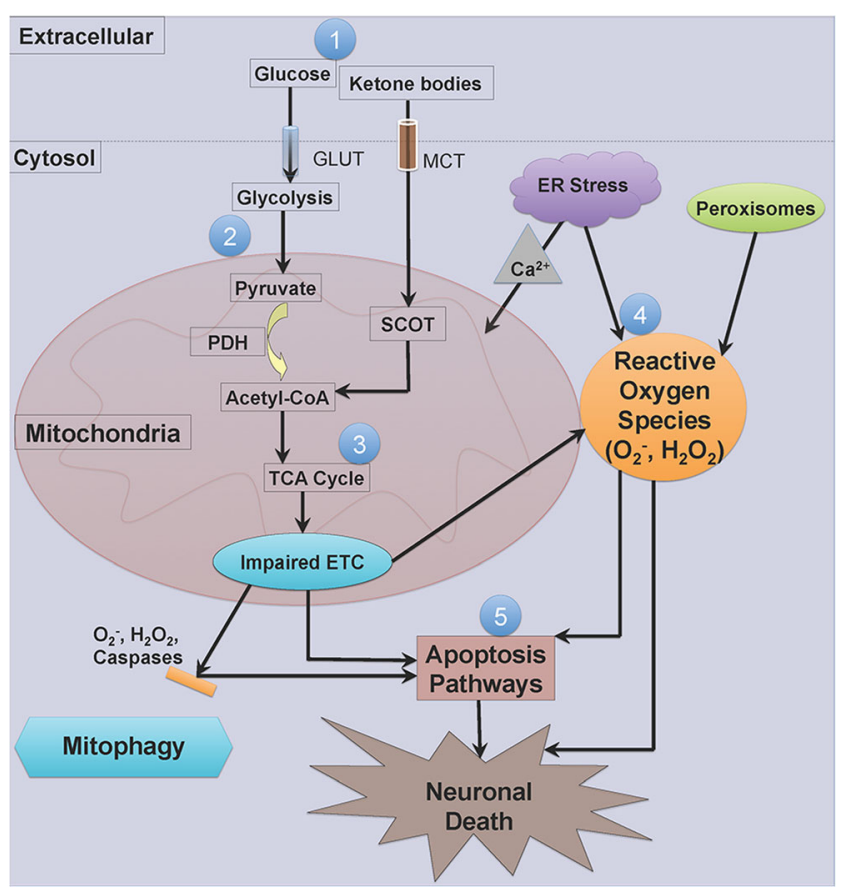

Fig. 2 Dysfunction of the brain energy production system precedes Alzheimer's disease (AD) pathology and neuronal death. Strategies to prevent mitochondrial dysfunction include multiple points of therapeutic intervention: 1) glucose or alternative fuel for substrate supply; 2) glycolysis; 3) the citric acid cycle (TCA) cycle and electron transport chain (ETC); 4) oxidative stress; 5) mitophagy and apoptosis. Mitochondrial impairments produce free radicals causing oxidative damage; reactive oxygen species and caspase proteases can block the neuroprotective mitophagy pathway. Mitochondrial dysfunction and endoplasmic reticulum (ER) stress activate apoptotic pathways that lead to neuronal loss and continuation of the AD pathology spectrum. GLUT $=$ glucose transporter; $\mathrm{MCT}=$ monocarboxylate transporter; $\mathrm{PDH}=$ pyruvate dehydrogenase; SCOT $=$ succinyl-coenzyme A:3-ketoacid CoA transferase both preclinical and clinical AD research. Decrements observed in cerebral glucose metabolism using fluoro-2deoxyglucose positron emission tomography (FDG-PET) and brain volume using magnetic resonance imaging are early signs of bioenergetic decline in the prodromal state of $\mathrm{AD}$ (Fig. 1) [16]. Observations from a clinical trial of the Dominantly Inherited Alzheimer's Network suggested several surrogate disease markers, including compromised FDG-PET signal in specific brain regions (posterior cingulate cortex and prefrontal cortex) vulnerable to development of $\mathrm{AD}$ pathology, that arise in patients with $\mathrm{AD}$ decades before cognitive symptoms [11-15, 17, 24, 44].

At the substrate level, glucose transport across the bloodbrain barrier (BBB) into neurons and glial cells require glucose transporters glial GLUT1 (55 kD and $45 \mathrm{kD}$ ), neuronal GLUT3, and insulin-dependent GLUT4 [31]. Glycolysis, the citric acid cycle, and mitochondrial oxidative phosphorylation are then coordinated to generate ATP [31, 32]. Compromised glucose uptake and metabolism provide a therapeutic target for AD prevention and intervention. Therapeutic candidates that target glucose metabolism could address the hypometabolic phenotype. If glucose hypometabolism in brain is a causative factor in development of $\mathrm{AD}$, then detection, prevention, and reversal of bioenergetic decline represent a therapeutic target window for AD [45]. Insulin is a therapeutic candidate to promote glucose metabolism in the brain (Table 1) $[46,47]$. Insulin plays an essential role in energy metabolism in the brain, with receptors densely populating the medial temporal regions of the brain required for memory formation [46]. Additionally, insulin-sensitive glucose transporters (GLUT4) are expressed in regions supporting memory and cognitive function [46]. Insulin resistance, which is the reduced sensitivity of insulin in targeted tissues important for cognitive function, increases the risk of dementia [47]. Impaired insulin responsiveness and dysfunctional glucose utilization have been documented in postmortem AD brains [48, 49]. Intranasal insulin was tested in a randomized, doubleblind, placebo controlled clinical study of 64 participants with mild cognitive impairment (MCI) and 40 participants with mild-to-moderate AD. Insulin-induced modest recovery of memory function and preservation of glucose uptake [50, 51]. A larger-scale Phase II/III trial is currently underway to examine the effects of intranasally administered insulin on cognition, entorhinal cortex and hippocampal atrophy, and cerebrospinal fluid biomarkers in amnestic MCI or mild AD (ClinicalTrials.gov identifier: NCT01767909).

In addition to glucose, an alternative fuel source, ketone bodies, is used for cellular processes when glucose and carbohydrate supply is low (Table 1; Fig. 2) [33, 62]. Ketone bodies are formed in the liver from fatty acid oxidation and are transported to the brain $[31,62,63]$. Ketone bodies, transported into the cell via monocarboxylate transporters, bypassing glycolysis, are subsequently utilized by a series of 
Table 1 Substrate supply

\begin{tabular}{lllll}
\hline $\begin{array}{l}\text { Substrate } \\
\text { supply }\end{array}$ & Mechanism/target & Preclinical experimentation & Clinical experimentation for AD & Reference \\
\hline Insulin & $\begin{array}{c}\text { Combat insulin-resistance, } \\
\text { increase brain metabolism }\end{array}$ & Beneficial in mouse models for AD & Phase II/III trials underway & [46-55] \\
$\begin{array}{c}\text { Ketone } \\
\text { bodies } \\
\text { metabolism }\end{array}$ & $\begin{array}{c}\text { Beneficial for motor function in animal } \\
\text { models and had cognition sparing properties }\end{array}$ & $\begin{array}{c}\text { Limited clinical data showed } \\
\text { improvements in cognitive testing }\end{array}$ \\
\hline
\end{tabular}

$\mathrm{AD}=$ Alzheimer's disease

ketolytic enzymes such as succinyl-coenzyme A (CoA):3ketoacid CoA transferase instead of pyruvate dehydrogenase (PDH) to produce acetyl-CoA, which condenses with oxaloacetate and enters the citric acid cycle for energy production $[31,62]$. Several therapeutic strategies aim to enhance brain bioenergetics through supplementation of ketone bodies, including acetoacetate and $\beta$-hydroxybutyrate $[64,65]$, or dietary induction of ketogenesis [56]. However, patient compliance on ketogenic diets is challenging owing to its high fat and low carbohydrate content. In addition, there are studies indicating that ketone bodies have little effect on AD pathology, despite benefits on motor performance [57, 66]. Two early proof-of-concept clinical studies, investigating ketone bodies for mild-to-moderate $\mathrm{AD}$, reported significant improvements on multiple measures of cognition $[58,59]$. Further research is required to verify whether supplementation of ketone bodies is an effective therapeutic approach for AD. Future research could develop forms of ketogenic supplementation for alternative energy.

The use of exogenous insulin and ketone bodies is mechanistically sound. However, supply of substrate or activation of a single target within the system, such as insulin receptors presumes that the entire bioenergetics system is fully functional, which is unlikely but not impossible. Supplementation with insulin or ketone bodies could promote substrate supply, (glucose or ketone bodies, respectively); however, substrate alone is unlikely to result in full recovery of the bioenergetics system or restore mitochondrial function.

\section{Mitochondrial Bioenergetics as a Therapeutic Target}

Multiple experimental paradigms, ranging from in vitro cell model systems and genomic analyses in animal models to postmortem autopsy of human brain and human brain imaging indicate deficits in mitochondrial function are consistent antecedents to AD development [11-13, 24]. A decline in mitochondrial function can occur decades prior to clinical diagnosis of $\mathrm{AD}$ and thus may serve as a biomarker of $\mathrm{AD}$ risk, as well as a therapeutic target $[12,24,32,67]$. Preclinical in vitro and in vivo AD models have demonstrated a decline in mitochondrial function, including reduced mitochondrial respiration, decreased metabolic enzyme expression and activity, increased oxidative stress, and increased mitochondrial $\mathrm{A} \beta$ load and $\mathrm{ABAD}$ expression, prior to $\mathrm{AD}$ pathology $[12,13$, $15,24,34,38]$. A series of mitochondrial enhancer candidates have been proposed and investigated in preclinical and clinical studies for AD prevention and treatment (Table 2).

Multiple candidate molecules target the electron transport chain (ETC). Coenzyme Q (CoQ) and its synthetic watersoluble analogue, idebenone, have been proposed for $\mathrm{AD}$ treatment $[32,68,83]$. CoQ is imbedded in the mitochondrial inner membrane and transports electrons from complex I/II to complex III in the ETC. In addition, CoQ can function as a ROS scavenger [68]. While CoQ supplementation has benefit in persons with CoQ synthesis disorders and in preclinical mouse models of $\mathrm{AD}$, it is ineffective as a therapeutic in persons with $\mathrm{AD}[32,65,83]$. In a randomized, double-blind, multicenter study with 450 participants with mild-to-moderate AD, Idebenone showed minimal cognitive benefit [69-71], but was not approved for treatment of AD based on results not reaching statistical significance in larger trials [70-72]. Methylene blue can enhance cytochrome c oxidase activity through direct electron donation $[80,81]$. In a preclinical AD mouse model, methylene blue treatment reduced Tau-neurofibrillary tangle burden [82]. Clinical investigations of methylene blue as a treatment for AD have not been conducted. Menadione and ascorbate together can act as complex IV substrates and sustain mitochondrial ETC respiration when complex III is compromised [79]. Other compounds that enhance mitochondrial ETC and oxidative phosphorylation include nicotinamide, a precursor to the complex I substrate, nicotinamide adenine dinucleotide, and riboflavin, a precursor to the complex II substrate, flavin adenine dinucleotdie [84]. While outcomes of research on these molecules have shown promising potential in preclinical studies, their efficacy clinically is unlikely to be substantial as they target specific components of the bioenergetic system instead of the entire system. A case in point is creatine, which is proposed to increase energy storage capacity and could be used to generate ATP under high-energy demands. However, creatine failed in clinical trials and in some cases even caused negative effects [86, 87].

Activation of the peroxisome proliferator-activated receptor- $\gamma$ and the peroxisome proliferator-activated receptor gamma coactivator $1-\alpha$ (PGC1 $\alpha$ ) pathway promote mitochondrial biogenesis $[73,74,83]$. Therapeutic candidates in this class include peroxisome proliferator-activated receptor- $\gamma$ 
Table 2 Mitochondrial enhancers

\begin{tabular}{|c|c|c|c|c|}
\hline Mitochondrial enhancers & Mechanism/target & Preclinical experimentation & Clinical experimentation for $\mathrm{AD}$ & Reference(s) \\
\hline $\begin{array}{l}\text { Coenzyme Q and } \\
\text { idebenone }\end{array}$ & $\begin{array}{l}\text { Accepts electron from complex I/II } \\
\text { delivering them to complex III, } \\
\text { scavenges ROS }\end{array}$ & $\begin{array}{l}\text { Slowed cognitive decline in } \\
\text { transgenic mouse models of } \mathrm{AD}\end{array}$ & $\begin{array}{l}\text { Failed in clinical trials insignificant } \\
\text { effects on cognition }\end{array}$ & {$[68-72]$} \\
\hline $\begin{array}{l}\text { Rosiglitazone } \\
\quad \text { (thiazolidinedione) }\end{array}$ & Activates PGC1 $\alpha$ & $\begin{array}{l}\text { Stimulate neuronal mitochondrial } \\
\text { biogenesis }\end{array}$ & $\begin{array}{l}\text { No significance in clinical trial, } \\
\text { poor penetration of BBB }\end{array}$ & {$[73-77]$} \\
\hline $\begin{array}{l}\text { Pioglitazone } \\
\quad \text { (thiazolidinedione) }\end{array}$ & Activates PGC1 $\alpha$ & $\begin{array}{l}\text { Reduced memory loss in mouse } \\
\text { models of } \mathrm{AD}\end{array}$ & $\begin{array}{l}\text { Small benefit in human select } \\
\text { groups; larger trials underway }\end{array}$ & {$[73-78]$} \\
\hline Bezafibrate & Activates PGC1 $\alpha$ & $\begin{array}{l}\text { Improves bioenergetics in } \\
\text { cell/animal models with } \\
\text { mitochondrial dysfunction }\end{array}$ & No clinical data & {$[73-77]$} \\
\hline Menadione and ascorbate & $\begin{array}{l}\text { Allow ETC flux to replace } \\
\text { defective complex III enzymes }\end{array}$ & $\begin{array}{l}\text { Increased bioenergetics in animal } \\
\text { models }\end{array}$ & $\begin{array}{l}\text { No significant effects in clinical } \\
\text { trials }\end{array}$ & [79] \\
\hline Methylene blue & $\begin{array}{l}\text { Tau inhibitor enhances COX } \\
\text { activity/anti-NRTs agent }\end{array}$ & $\begin{array}{l}\text { Improved bioenergetics in cell } \\
\text { culture and animal models }\end{array}$ & No clinical data & {$[80-82]$} \\
\hline $\begin{array}{l}\text { Riboflavin and } \\
\text { nicotinamide }\end{array}$ & Precursors to FADH 2 and NADH & Increased mitochondrial respiration & No clinical data & {$[83-85]$} \\
\hline Creatine & $\begin{array}{l}\text { Cells to store creatine phosphate as } \\
\text { alternative energy source }\end{array}$ & Increase in cell bioenergetics & $\begin{array}{l}\text { Benefits for muscle strength, } \\
\text { negative effects on cognition } \\
\text { in clinical trials }\end{array}$ & {$[79,86-88]$} \\
\hline Exogenous TFAM & $\begin{array}{l}\text { Important for mtDNA } \\
\text { replication/transcription, } \\
\text { administered with a } \\
\text { mitochondrial leader sequence } \\
\text { and protein transduction domain }\end{array}$ & $\begin{array}{l}\text { Increased respiration and } \\
\text { mitochondrial biogenesis in cell } \\
\text { culture and mouse tissues }\end{array}$ & No clinical data & [89-91] \\
\hline
\end{tabular}

$\mathrm{AD}=$ Alzheimer's disease; $\mathrm{ROS}=$ reactive oxygen species; $\mathrm{PGC1} \alpha=$ peroxisome proliferator-activated receptor gamma coactivator 1 -alpha; $\mathrm{BBB}=$ blood-brain barrier; ETC = electron transport chain; COX = cyclooxygenase; NFT = neurofibrillary tangle; FADH2 = flavin adenine dinucleotide; $\mathrm{NADH}=$ nicotinamide adenine dinucleotide; TFAM = mitochondrial transcription factor $\mathrm{A} ; \mathrm{mtDNA}=$ mitochondrial DNA

agonist thiazolidinediones, pioglitazone and rosiglitazone, as well as the PGC1 $\alpha$ activator Bezafibrate. Activation of PGC $1 \alpha$ by Bezafibrate was reported to improve cell bioenergetics and decrease mitochondrial dysfunction in cell culture and animal models [73, 74].

Preclinically, pioglitazone restored cerebrovascular function, reduced oxidative stress, and increased mitochondrial respiration [75-77]. Pioglitazone was initially tested in the human neuron-like NT2 cell line, where it induced mitochondrial biogenesis, increased mtDNA content and subunit proteins, and reduced mitochondrial oxidative damage [78]. Rosiglitazone stimulated neuronal mitochondrial biogenesis and reduced memory deficits in mouse models of $\mathrm{AD}$ [75-77]. A small clinical trial of 32 patients with mild AD showed significant improvements with pioglitazone treatment on both the AD Assessment Scale-Cognitive subscale scores and Wechsler Memory Scale-Revised Logical Memory Performance tests $[92,93]$. The patients also had improved cerebral blood flow in parietal lobes [93]. A Phase III clinical trial of pioglitazone for $\mathrm{MCI}$ due to $\mathrm{AD}$ is currently underway (ClinicalTrials.gov identifier: NCT01931566). Rosiglitazone tested in MCI and early AD showed improved delayed recall [94], but failed to show significant cognitive benefits in a subsequent larger trial with over 1400 patients with mild-tomoderate AD (ClinicalTrials.gov identifier: NCT00490568) [95]. One major challenge for these candidates is they have poor BBB penetration [78]. However, if co-transported through the $\mathrm{BBB}$, rosiglitazone and other thiazolidinediones could be therapeutically beneficial in preventing AD.

Another potential target of the mitochondrial biogenesis pathway is the mitochondrial transcription factor A (TFAM), which is involved in mitochondrial biogenesis, mtDNA replication, transcription, and removal of homoplasmic mtDNA mutations [96]. In vitro administration of TFAM reportedly increased mitochondrial respiration rates, biogenesis, and mtDNA levels [89-91]. The potential of TFAM as a therapeutic is unlikely owing to its large size and difficulty in BBB penetration [97]. However, targeting expression of TFAM could be a therapeutic strategy to enhance mitochondrial bioenergetics.

Mitochondrial enhancers have been demonstrated to be effective in preclinical models of AD (Table 2), whereas clinical trials testing this strategy directly remain to be conducted. Targeting mitochondria directly assumes that the bioenergetic system of substrate transporters and metabolism are fully functional. This is unlikely to be the case in the prodromal and later stages of the disease based on clinical FDG-PET data indicating impaired glucose metabolism decades prior to AD diagnosis. Mitochondrial function is inextricably linked to upstream substrate supply and metabolism. Thus, increasing mitochondrial function in the presence of dysfunctional substrate transport and metabolism could exacerbate 
degeneration. However, therapeutic strategies that promote each functional domain of the bioenergetic system, including mitochondrial function, could have benefit.

\section{Oxidative Damage as a Therapeutic Target}

A well-documented indicator of compromised mitochondrial function is oxidative stress [83, 85, 98-100]. Oxidative stress is primarily caused by excessive ROS produced by impaired electron transport, endoplasmic reticulum stress, and peroxisomes (Fig. 2) [24, 83, 98, 101, 102]. Decreases in enzymatic antioxidant defense capacity, including multiple superoxide dismutases (SOD), peroxiredoxins, and glutathione [103, 104], further exacerbates oxidative damage [83, 85, 98, 100]. Oxidative damage of multiple cellular components has been documented in both preclinical models of $\mathrm{AD}$ and in persons with the disease $[102,105]$. Key enzymes involved in mitochondrial function, such as PDH and $\alpha$-ketoglutarate dehydrogenase, are often targeted by ROS, leading to deceased enzyme activity and decreased efficiency of mitochondrial electron transport (Fig. 2) [106]. In AD, elevated oxidative stress is detectable in the form of lipid peroxides, 8oxoguanine, and other oxidized proteins [107-110]. In parallel, oxidative stress has been demonstrated to increase $A \beta$ production in vitro and in vivo [102, 109].

Several candidates have been proposed to prevent or reduce oxidative damage, and have been investigated as treatments for AD (Table 3). Deficits in plasma levels of antioxidants are well documented in patients with $\mathrm{AD}[111,112$, 140]. Early research administering antioxidants for AD treatment focused on vitamins $\mathrm{C}$ and $\mathrm{E}$. Both these vitamins are significantly reduced in the plasma of patients with $\mathrm{AD}$ [111]. Multiple preclinical studies on vitamin $\mathrm{C}$ and vitamin $\mathrm{E}$ using transgenic $\mathrm{AD}$ mouse models indicated decreased lipid peroxidation, memory deficits, and $A \beta$ plaque burden [114-116]. However, clinically, vitamins $\mathrm{C}$ and $\mathrm{E}$ showed limited benefits on cognitive function or delay of AD progression [117-119, 141]. Some studies indicated negative effects of high-dose vitamin $\mathrm{E}$ on cognitive function and increased risk for mortality [142]. A more recent randomized trial of vitamin $\mathrm{E}$ in veterans showed a $19 \%$ delay in clinical progression per year [120]. In addition to vitamins $\mathrm{C}$ and $\mathrm{E}$, several other antioxidant vitamins, including vitamins $\mathrm{A}, \mathrm{B}_{12}$, and $\mathrm{D}$, have been investigated owing to their deficient levels in patients with $\mathrm{AD}$ $[111,113]$. These vitamins failed to show significant efficacy when used in clinical settings (ClinicalTrials.gov identifier: NCT00235716), despite positive outcomes in preclinical models. Currently, these vitamins are often used in combination with other therapeutics based on their general health benefits.

Micronutrients and minerals have been investigated as potential therapeutics for AD. These include, but are not limited to, flavonoids (e.g., quercetin, morin, or baicalein), $\beta$-carotene, curcumin, zinc, folic acid, and selenium. Most of these showed little promise as an AD therapeutic on their own, but when combined together in formulations they improved cognitive function in transgenic $\mathrm{AD}$ mice and reduced oxidative stress $[129,130]$.

Curcumin is an antioxidant that has been demonstrated to induce multiple benefits in $\mathrm{AD}$ mouse models. In addition to its strong antioxidant ability, it has anti-inflammatory activity, reduces amyloid plaque burden, and partially restored distorted neuritis [125-128]. A current Phase II clinical trial that combines curcumin and yoga therapy aims to treat MCI (ClinicalTrials.gov identifier: NCT01811381). Resveratrol found in red grape skin is a potent antioxidant that has been shown to reduce amyloid plaque burden and improve memory deficits in transgenic AD mouse models [132, 133]. Resveratrol activates the 5'adenosine monophosphate-activated protein kinase pathway, and stimulates activity of nicotinamide adenine dinucleotide-dependent deacetylase sirtuin-1 [134, 135], which subsequently activates the PGC1 $\alpha$ metabolic regulatory pathway and promotes mitochondrial biogenesis [136-139]. Several clinical trials are currently underway to investigate the efficacy of resveratrol, including a Phase II trial on mild-to-moderate $\mathrm{AD}$ (ClinicalTrials.gov identifier: NCT01504854), a Phase III on mild-to-moderate AD (ClinicalTrials.gov identifier: NCT00743743), and a Phase IV on MCI, which combines resveratrol with omega-3 (ClinicalTrials.gov identifier: NCT01219244).

There is also a set of compounds, including melatonin, that promote expression of mitochondrial antioxidant enzymes such as SOD or glutathione [121-124]. Mitoquinone mesylate (MitoQ) has been proposed for treatment of $\mathrm{AD}$ and other neurodegenerative diseases because its antioxidant activity localizes to the mitochondrial inner membrane to prevent oxidative damage [131]. MitoQ has shown bioenergetic benefits in $\mathrm{AD}$ mouse models, but the clinical benefit of MitoQ for patients with $\mathrm{AD}$ is yet to be determined [131].

Overall, strategies based on antioxidants and micronutrients have shown promise in transgenic AD models, but their clinical therapeutic efficacy has not been established under disease conditions. Further, their therapeutic potential in combination with factors that target the entire bioenergetic system in the at-risk and prodromal stages of the disease has yet to be investigated (Fig. 1). Therapeutics that selectively target the oxidative damage and act as free radical scavengers may offer moderate symptom alleviation if administered early in disease progress, but will not address the pathogenic cascade and therefore are unlikely to modify disease progression. Further, oxidative stress is unlikely to be causative for $\mathrm{AD}$, but rather an outcome of mitochondrial dysfunction. Thus, free radical scavengers should be considered as a critical but not sufficient component of a formulation that targets the bioenergetics system. 
Table 3 Antioxidants and micronutrients

\begin{tabular}{|c|c|c|c|c|}
\hline $\begin{array}{l}\text { Antioxidants and } \\
\text { micronutrients }\end{array}$ & Mechanism/target & Preclinical experimentation & Clinical experimentation for $\mathrm{AD}$ & Reference(s) \\
\hline Vitamin A & Oxidative stress, ROS scavenger & $\begin{array}{l}\text { In vitro and mouse models of } \mathrm{AD} \\
\text { confirm mechanism }\end{array}$ & No significant effects in clinical trials & [111-113] \\
\hline Vitamin $B_{12}$ & Oxidative stress, ROS scavenger & $\begin{array}{l}\text { In vitro and mouse models of } \mathrm{AD} \\
\text { confirm mechanism }\end{array}$ & No significant effects in clinical trials & {$[111-113]$} \\
\hline Vitamin C & Oxidative stress, ROS scavenger & $\begin{array}{l}\text { Reduced memory deficits in mouse } \\
\text { models of AD }\end{array}$ & No significant effects in clinical trials & {$[114-118]$} \\
\hline Vitamin D & Oxidative stress, ROS scavenger & Minimal effects in mouse models of AD & No significant effects in clinical trials & {$[111-113]$} \\
\hline $\begin{array}{l}\text { Vitamin E } \\
\qquad(\alpha \text {-Tocopherol })\end{array}$ & Oxidative stress, ROS scavenger & $\begin{array}{l}\text { Reduce ROS, lipid peroxidation and } \\
\text { amyloid plaque in transgenic } \\
\text { mouse models of } \mathrm{AD}\end{array}$ & $\begin{array}{l}\text { Multiple trials with no effect, recent } \\
\text { clinical trial indicating delay in } \\
\text { clinical progression, but high dose } \\
\text { increased risk of mortality }\end{array}$ & {$[114-120]$} \\
\hline Melatonin & $\begin{array}{l}\text { Potent antioxidant, elevates } \\
\text { levels of SOD and glutathione }\end{array}$ & $\begin{array}{l}\text { Reduced oxidative stress increased } \\
\text { learning ability in mouse models } \\
\text { of } \mathrm{AD}\end{array}$ & No clinical data & {$[121-124]$} \\
\hline Curcumin & $\begin{array}{l}\text { Antioxidant and } \\
\text { anti-inflammatory activity }\end{array}$ & $\begin{array}{l}\text { In vitro and mouse models of } \mathrm{AD} \\
\text { confirm mechanism }\end{array}$ & No significant effects in clinical trials & {$[125-128]$} \\
\hline Folic acid & Oxidative stress, ROS scavenger & $\begin{array}{l}\text { In vitro and mouse models of } \mathrm{AD} \\
\text { confirm mechanism }\end{array}$ & No significant effects in clinical trials & {$[129,130]$} \\
\hline$\beta$-Carotene & Oxidative stress, ROS scavenger & $\begin{array}{l}\text { In vitro and mouse models of } \mathrm{AD} \\
\text { confirm mechanism }\end{array}$ & No significant effects in clinical trials & {$[129,130]$} \\
\hline Flavonoids & Oxidative stress, ROS scavenger & $\begin{array}{l}\text { In vitro and mouse models of } \mathrm{AD} \\
\text { confirm mechanism }\end{array}$ & No significant effects in clinical trials & {$[129,130]$} \\
\hline Zinc & Reduce oxidative stress & $\begin{array}{l}\text { Combined with micronutrients } \\
\text { decreased oxidative damage/ } \\
\text { increased bioenergetics }\end{array}$ & No significant effects in clinical trials & {$[129,130]$} \\
\hline Selenium & Oxidative stress, ROS scavenger & $\begin{array}{l}\text { Mixed results when used alone, but } \\
\text { effective in animal models in } \\
\text { combinations }\end{array}$ & No significant effects in clinical trials & {$[129,130]$} \\
\hline MitoQ & Oxidative stress, ROS scavenger & $\begin{array}{l}\text { Extended lifespan in mouse models } \\
\text { of } \mathrm{AD}\end{array}$ & No clinical data for $\mathrm{AD}$ & [131] \\
\hline Resveratrol & $\begin{array}{l}\text { Activation of AMPK subsequent } \\
\text { induction of NAD+ levels } \\
\text { stimulate activity of SIRT1 }\end{array}$ & $\begin{array}{l}\text { Reduces oxidative stress, reduces } \\
\text { amyloid plaques, improves } \\
\text { memory deficits in transgenic } \\
\text { mouse models of AD }\end{array}$ & No major effect on cognitive function & {$[132-139]$} \\
\hline
\end{tabular}

$\mathrm{AD}=$ Alzheimer's disease; $\mathrm{ROS}=$ reactive oxygen species; $\mathrm{SOD}=$ superoxide dismutase; Mito $\mathrm{Q}=$ mitoquinone mesylate; $\mathrm{AMPK}=$ adenosine monophosphate-activated protein kinase; $\mathrm{NAD}=$ nicotinamide adenine dinucleotide; $\mathrm{SIRT} 1=$ sirtuin 1

Apoptosis and Mitophagy as Therapeutic Targets

Prolonged deficits in bioenergetics together with elevated oxidative stress lead to activation of apoptotic pathways, impaired mitophagy, and, ultimately, neuronal death [143]. Mitochondrial autophagy, often referred to as mitophagy, is a highly dynamic process for disposal and recycling of unhealthy mitochondria [143]. A balance between mitophagy and mitochondrial biogenesis provides an efficient energy transducing system required for neuronal survival [144], whereas mitochondrial dysfunction contributes to neuronal death and AD pathology (Fig. 2) [98, 123, 145]. Elevated oxidative stress and induction of apoptotic proteases can inactivate mitophagy and impair pathways required for clearance of aberrant mitochondria [83, 85, 101, 146, 147].

Several therapeutic strategies target the autophagy and mitophagy pathways (Table 4). Based on its potential to induce autophagy in several neurodegenerative disease models, Rapamycin, also known as sirolimus, is being investigated for AD [148-150]. Mechanisms of rapamycin action include removal of damaged mitochondria and cells with dysfunctional mitochondria via mammalian target of rapamycin-dependent activation of autophagy [149, 150]. Rapamycin extends lifespan in aged mice [148]. In transgenic $\mathrm{AD}$ mouse models, rapamycin reduced $\mathrm{A} \beta$ plaques and prevented cognitive decline [148, 149, 151]. However, the therapeutic development of rapamycin for treatment of neurodegenerative diseases was largely hampered by severe side effects, including lung toxicity, diabetes, and cancer [151].

Latrepirdine, also known as Dimebon, is an antihistamine that, in cell culture, reduced swelling of mitochondria under $\mathrm{A} \beta$ stress and stabilized mitochondrial membrane potentials $[145,152]$. Latrepirdine is proposed to interact with glutamate 
Table 4 Antiapoptotic and mitophagy strategies

\begin{tabular}{|c|c|c|c|c|}
\hline $\begin{array}{l}\text { Antiapoptotic and } \\
\text { mitophagy strategies }\end{array}$ & Mechanism/target & $\begin{array}{l}\text { Preclinical } \\
\text { experimentation }\end{array}$ & Clinical experimentation for $\mathrm{AD}$ & References \\
\hline Rapamycin & $\begin{array}{l}\text { Targets and inhibits the mTOR } \\
\text { complex } 1\end{array}$ & $\begin{array}{l}\text { Reduced and prevented cognitive } \\
\text { decline and } \mathrm{A} \beta \text { levels in mouse } \\
\text { models of } \mathrm{AD}\end{array}$ & $\begin{array}{l}\text { No clinical trials available for } \\
\text { AD, side effects in other uses } \\
\text { include cancer, lung toxicity, } \\
\text { and diabetes }\end{array}$ & {$[148-151]$} \\
\hline Latrepirdine (Dimebon) & $\begin{array}{l}\text { Antihistamine, some mitochondrial } \\
\text { stabilizing properties }\end{array}$ & Transgenic mouse models of AD & $\begin{array}{l}\text { Phase II success improved } \\
\text { function, but no effect in the } \\
\text { larger Phase III; some yet to } \\
\text { be reported }\end{array}$ & {$[152-157]$} \\
\hline $\begin{array}{l}\text { Lentiviral vector } \\
\text { expressing } \mathrm{Nrf} 2\end{array}$ & $\begin{array}{l}\text { Intrahippocampal injection of lentiviral } \\
\text { vector expressing Nrf2, a master } \\
\text { regulator of the antioxidant pathway, } \\
\text { induces expression of antioxidant } \\
\text { enzymes }\end{array}$ & $\begin{array}{l}\text { Hippocampal cells in vitro and } \\
\text { mouse models of } \mathrm{AD}\end{array}$ & No clinical data & {$[158,159]$} \\
\hline Synthetic triterpenoids & $\begin{array}{l}\text { Suppress inflammatory stress and } \\
\text { oxidative damage by activating } \\
\text { Nrf2 pathway }\end{array}$ & $\begin{array}{l}\text { Memory retention in transgenic } \\
\text { mouse models of } \mathrm{AD}\end{array}$ & No clinical data & {$[160,161]$} \\
\hline
\end{tabular}

$\mathrm{AD}=$ Alzheimer's disease $; \mathrm{mTOR}=$ mammalian target of rapamycin; $\mathrm{A} \beta=\beta$-amyloid $; \mathrm{Nrf2}=$ nuclear response factor 2

receptors, block voltage-dependent calcium channels, and inhibit mitochondrial permeability, thereby suppressing unnecessary mitophagy or apoptosis $[153,154]$. In a Phase II clinical trial in patients with moderate $\mathrm{AD}$, it significantly improved cognitive function over placebo [155]. However, these results were not confirmed as Latrepirdine/Dimebon later failed in a larger Phase III trial of patients with moderate-to-severe AD (ClinicalTrials.gov identifier: NCT00912288) [156, 157].

Nuclear response factor 2 (Nrf2) and Nrf2/antioxidant response element have been proposed as a therapeutic target for autophagy and mitophagy. In transgenic AD mouse models intrahippocampal injections of the lentiviral vector expressing Nrf2 decreased $A \beta$ plaque, reduced learning deficits, and protected against $A \beta$-induced cell death $[158,159]$. Synthetic triterpenoids have been demonstrated to induce expression of $\mathrm{Nrf} 2$ and to protect against cell death in both in vitro and in vivo experiments [160,161]. Development of strategies that target this Nrf2/antioxidant response element pathway are at an early stage and require substantial translational research.

Preclinical strategies targeting autophagy and mitophagy pathways in AD models have shown cognitive benefits (Table 4). However, substantial preclinical discovery and translational research remain to be conducted to advance this therapeutic target. Targeting the apoptotic and mitophagy pathways alone as a therapeutic strategy does not address the causative mechanisms leading to disrupted mitophagy and elevated apoptosis. Though the research in this area of $\mathrm{AD}$ therapeutics awaits translational validation, apoptotic regulation and removal of dysfunctional mitochondria is critical to restoration of bioenergetic capacity in brain.

\section{Systems Approaches for AD Prevention and Treatment}

Alzheimer's is a neurodegenerative disease with a complex and progressive pathological phenotype characterized by antecedent hypometabolism, impaired mitochondrial bioenergetics, and oxidative damage followed by apoptotic and pathological burden. The progressive and multifaceted degenerative phenotype of AD suggests that successful treatment strategies would be equally multifaceted with a systems biological approach. Several systems biology approaches for AD prevention and treatment are in development (Table 5).

One of the widely accepted therapeutic strategies to prevent $\mathrm{AD}$ is diet and exercise. The systems-wide neuroprotective benefits of caloric restriction and exercise include activation of adaptive cellular stress responses, enhancement of DNA repair, promotion of mitochondrial biogenesis, and induction of neurotropic factors [162]. Previous preclinical studies using multiple forms of caloric restriction led to reduced abdominal fat mass, decreased cellular oxidative damage and proinflammatory cytokines [163-165, 194], and improved learning and memory function [60].

Exercise has also been investigated for its direct benefits for patients with AD. Exercise activates a full systems effect, including promotion of hippocampal neurogenesis, reduction of brain inflammation, and increased PGC1 $\alpha$ levels, mtDNA, proteins in ETC, and neurotropic factors [167-172]. Interestingly, a recent study demonstrated that the benefits of exercise were associated with elevated lactate levels and could be partially replicated by treatment with lactate [168].

Another lifestyle strategy for AD prevention is the Mediterranean diet (MeDi). MeDi, opposed to the Western diet, is characterized by the abundant consumption of plant foods such as vegetables, fruits, breads, potatoes, legumes, nuts, 
Table 5 Systems strategies

\begin{tabular}{|c|c|c|c|c|}
\hline $\begin{array}{l}\text { Systems } \\
\text { strategies }\end{array}$ & Mechanism/target & Preclinical experimentation & Clinical experimentation for $\mathrm{AD}$ & References \\
\hline $\begin{array}{l}\text { Restricted-calorie } \\
\text { diet }\end{array}$ & $\begin{array}{l}\text { Decrease oxidative damage } \\
\text { and increase lactate levels }\end{array}$ & $\begin{array}{l}\text { Controlled daily caloric restriction } \\
\text { reduced oxidative stress in vivo }\end{array}$ & Reduced oxidative damaged & {$[60,162-166]$} \\
\hline Exercise & $\begin{array}{l}\text { Decrease oxidative stress, } \\
\text { increased mitochondrial } \\
\text { function }\end{array}$ & $\begin{array}{l}\text { Decrease in oxidative damage and } \\
\text { amyloid plaque levels in vivo }\end{array}$ & $\begin{array}{l}\text { Increased cognitive function, } \\
\text { weight, and general health }\end{array}$ & $\begin{array}{l}{[135,136,162} \\
165,167-172]\end{array}$ \\
\hline $\begin{array}{l}\text { Mediterranean } \\
\text { diet }\end{array}$ & $\begin{array}{l}\text { Plant foods, e.g., fruits, } \\
\text { vegetables, roots, and grains }\end{array}$ & 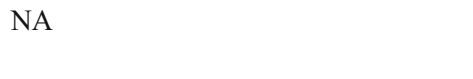 & $\begin{array}{l}\text { Epidemiological studies in } \\
\text { several countries }\end{array}$ & {$[113,173-181]$} \\
\hline $17-\beta$-estradiol & $\begin{array}{l}\text { Decrease oxidative stress, } \\
\text { increase glycolytic } \\
\text { metabolism, increase } \\
\text { mitochondrial respiration }\end{array}$ & $\begin{array}{l}\text { Decrease in oxidative damage and } \\
\text { amyloid plaque levels, increase in } \\
\text { mitochondria bioenergetics in vitro } \\
\text { and in vivo }\end{array}$ & $\begin{array}{l}\text { Transdermal patch aims to } \\
\text { improve cognition, possible } \\
\text { adverse side effects }\end{array}$ & $\begin{array}{r}{[9,33,110} \\
182-189]\end{array}$ \\
\hline $\begin{array}{l}\text { Clioquinol and } \\
\text { PBT2 }\end{array}$ & $\begin{array}{l}\text { Multifaceted antifungal drug; } \\
\text { metal chelator of } \mathrm{Zn} \text { and } \mathrm{Cu} \\
\text { targeting } \mathrm{A} \beta \text { plaque reactions }\end{array}$ & $\begin{array}{l}\text { Reversal of cognitive deficits in } \mathrm{AD} \\
\text { transgenic mice }\end{array}$ & Currently in clinical trials & {$[85,190-192]$} \\
\hline Souvenaid & 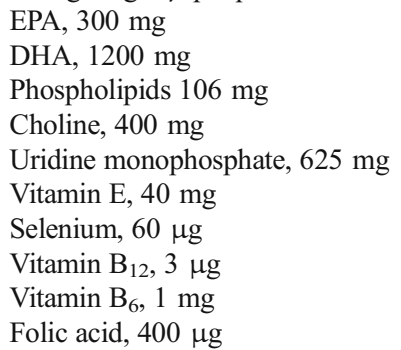 & $\begin{array}{l}\text { Protects in vivo system against } \mathrm{A} \beta \\
\text { toxicity in rat } \mathrm{A} \beta \text { infusion model } \\
\text { and transgenic mouse models of } \mathrm{AD}\end{array}$ & $\begin{array}{l}\text { Small-scale human trials; } \\
\text { improve cognitive function } \\
\text { and enhance synaptic activity } \\
\text { with EEG }\end{array}$ & {$[112,113,193]$} \\
\hline
\end{tabular}

$\mathrm{AD}=$ Alzheimer's disease; NA, not available; $\mathrm{A} \beta=\beta$-amyloid; EPA $=$ eicospentaenoic acid; $\mathrm{DHA}=$ docosahexaenoic acid; EEG = electroencephalography

and seeds; olive oil as the source of fat; moderate amounts of dairy, fish, poultry, and eggs; low intake of red meats; and wine during normal meals [173, 174, 195]. The nutrients within the MeDi influence biological mechanisms affecting vascular, antioxidant, and inflammatory pathways $[175,176]$. $\mathrm{MeDi}$ was demonstrated to reduce risk of heart disease, decrease markers of oxidative stress, and lower inflammatory markers; hence, MeDi adherence might delay age-related cognitive decline [177-180]. MeDi has shown a trend of benefiting cognitive function when assessed in population studies in 7 different countries [196]. Mechanistically, the cognitive benefits of the MeDi have been attributed to the synergistic interactions between antioxidants, B vitamins, omega-3 fatty acids, and other compounds [181, 197]. Questions remain about whether the benefits of the MeDi could be attributed to specific ingredients rather the complete diet [196]. Investigations on the mechanisms of MeDi action could identify key active ingredients that can be further developed into therapeutics for $\mathrm{AD}$ prevention and treatment.

Other than these lifestyle strategies there are also systems approaches for improving bioenergetics and mitochondrial function. One of the most investigated therapeutics in women is estrogen-containing hormone therapy. $17-\beta$-estradiol $\left(\mathrm{E}_{2}\right)$ activates multiple signaling pathways in the brain, including mitogen-activated protein kinase, phosphatidylinositol-3-kinase, $\mathrm{G}$ protein-regulated signaling, c-fos, protein kinase $\mathrm{C}$, and $\mathrm{Ca}^{2+}$ influx, which all are connected to neuronal function and survival $[9,182]$. The ovarian hormone loss in menopause has been linked with cognitive decline that increases the risk for $\mathrm{AD}[9,33,110,182-186] . \mathrm{E}_{2}$ treatment induced a significant increase in expression of glucose transporters and promotes aerobic glycolysis by increasing gylcolytic enzyme activity of hexokinase, phosphofructokinase, and pyruvate kinase $[187,188]$. Further, $\mathrm{E}_{2}$ activates PDH, enhances activities of the ETC complexes, and promotes ATP generation. The neurological benefits of $E_{2}$ are further enhanced by suppression of the oxidative stress via enhanced antioxidant capacity. $E_{2}$ also reduces $A D$ pathology by both decreasing the production and increasing the clearance of $\mathrm{A} \beta$ species [182]. The systems biology of $E_{2}$ action in the brain has led to the design and development of brain-specific candidates of selective estrogen receptor modulators that activate the systems level of estrogenic mechanisms in the brain without the proliferative side effects in the periphery $[110,183,185,186]$.

Clioquinol is a therapeutic candidate for treatment of $\mathrm{AD}$ with bioenergetic system benefits. Acting as a chelator for copper and zinc ions, clioquinol had significant success in preclinical studies with transgenic AD mouse models. Binding of metal ions is required for $A \beta$ aggregation and $A \beta$ induced free radical release in mitochondria [190]. A secondgeneration clioquinol molecule, PBT2, is in Phase II clinical trials (ClinicalTrials.gov identifier: NCT00471211). PBT2 
reportedly decreased $\mathrm{A} \beta$ levels and improved performance on 2 cognitive function tests $[191,192]$. In addition to metal chelation, PBT2 has a second mechanistic action to increase $A \beta$ clearance, increasing activity of matrix metalloproteases including neprilysin, insulin degrading enzyme, and tissue plasminogen activator [191, 192].

Souvenaid was originally developed to improve nutrient deficiencies common in patients with $\mathrm{AD}$ and contains high doses of the omega-3 fatty acids eicospentaenoic acid and docosahexaenoic acid [112]. The formulation also acts as a ketogenic dietary supplement with high fat content to provide ketone bodies to the brain. The formulation also contains antioxidants; vitamins A, C, E, riboflavin, and folic acid; selenium; and ions required for membrane potential balancing and mitochondrial function, including sodium, potassium, chloride, calcium, and zinc [193]. In a 24-week double-blind sex-balanced clinical trial with 259 patients aged 51-89 years (mean 74 years) with mild AD, Souvenaid significantly improved memory and synaptic connectivity measured by electroencephalography [193]. However, in a clinical trial with patients with moderate-to-severe $\mathrm{AD}$, no significant improvement was associated with Souvenaid treatment [112, 193], suggesting that the intervention window is early in $\mathrm{AD}$ progression.

System-wide approaches for therapeutic intervention have greater potential for clinical success in chronic progressive neurodegenerative diseases like AD. Systems biology therapeutic strategies address dysfunction of multiple components of the bioenergetic system and thus have a higher probability for efficacy. Future approaches will need to address early antecedent deficits in substrate supply, mitochondrial function, and apoptotic pathways in the bioenergetic system to avoid development of severe irreversible AD pathology.

\section{Summary and Concluding Comments}

The bioenergetic system is a complex network of pathways responsible for energy production required for neurological function and health. Current preventive strategies to target brain mitochondria focus on antioxidants, antiapoptosis agents, and bioenergetic enhancement. Several of these strategies have shown efficacy in preclinical investigations; however, most interventions have not translated to success in preventing, delaying, or reversing cognitive decline in clinical investigations.

A large body of evidence indicates that targeting one component of a neurobiological system does not create a course of correction nor does it reverse a system failure. For example, targeting oxidative stress does not alleviate the glucose hypometabolism or mitochondrial dysfunction, which are likely to be the primary failure points of the system from which oxidative stress emerges. Attempts to target the bioenergetic system in $\mathrm{AD}$ face the challenge of a dynamic adapting system that requires biomarkers specific to the bioenergetic state and precision therapeutics that target the bioenergetic phenotype during the window of opportunity.

The prodromal/preclinical state is a critical window in which to prevent progression to AD (Fig. 1). This window of opportunity is likely to be addressed through a combination of dietary supplements and nutraceuticals. Dietary supplements are defined as products that intend to supplement diet containing $\geq 1$ of several dietary ingredients: vitamins, minerals, herbs, amino acids, concentrates, metabolites, or combinations of such [198]. Nutraceuticals, which may include 1 or many of the components in dietary supplements, intend to aid in prevention or treatment of disease or disorder [198]. Nutraceuticals hold promise as effective modifiers of multifaceted cellular pathways that are defective in the prodromal state of AD. Numerous vitamins and natural compounds elicit effects on specific targets of the bioenergetic system in the brain; some micronutrients may offset the deficiencies often associated with early AD $[111,112]$. Natural compounds combined into a synergistic formulation could provide an effective nutraceutical-based mode of prevention for $\mathrm{AD}$ and other neurodegenerative disorders. Effective strategies that target the prodromal AD window could combine the benefits of bioenergetic system enhancers to promote glucose metabolism, reduce oxidative stress, and sustain normal mitophagy. The systems biology-based therapeutic strategy to prevent early bioenergetic deficits in the brain could have a major impact on future incidence of $\mathrm{AD}$.

Acknowledgments This work was supported by National Institute on Aging (NIA) grants R01AG032236 (to R.D.B.), P01AG026572 (to R.D.B.), and R01AG033288 (to R.D.B.). We thank Dr. Ronald Irwin for helpful discussions throughout the process of developing this review.

Required Author Forms Disclosure forms provided by the authors are available with the online version of this article.

\section{References}

1. World Health Organization. Dementia: a public health priority. Geneva, World Health Organization, 2012.

2. Brookmeyer R, Johnson E, Ziegler-Graham K, Arrighi HM. Forecasting the global burden of Alzheimer's disease. Alzheimers Dement 2007;3:186-191.

3. Ferri CP, Prince M, Brayne C, et al. Global prevalence of dementia: a Delphi consensus study. Lancet 2005;366:2112-2117.

4. Feldman HH, Haas M, Gandy S, et al. Alzheimer's disease research and development: a call for a new research roadmap. Ann N Y Acad Sci 2014;1313:1-16.

5. Lin PJ, Yang Z, Fillit HM, Cohen JT, Neumann PJ. Unintended benefits: the potential economic impact of addressing risk factors to prevent Alzheimer's disease. Health Affairs 2014;33:547-554.

6. Thies W, Bleiler L. 2013 Alzheimer's disease facts and figures. Alzheimers Dement 2013;9:208-245. 
7. Karran E, Mercken M, De Strooper B. The amyloid cascade hypothesis for Alzheimer's disease: an appraisal for the development of therapeutics. Nat Rev Drug Discov 2011;10(9):698-712.

8. Morris JK, Honea RA, Vidoni ED, Swerdlow RH, Burns JM. Is Alzheimer's disease a systemic disease? Biochim Biophys Acta 2014;1842:1340-1349.

9. Brinton RD. Estrogen regulation of glucose metabolism and mitochondrial function: therapeutic implications for prevention of Alzheimer's disease. Adv Drug Deliv Rev 2008;60:1504-1511.

10. Irwin RW, Solinsky CM, Brinton RD. Frontiers in therapeutic development of allopregnanolone for Alzheimer's disease and other neurological disorders. Front Cell Neurosci 2014;8:1-19.

11. Gibson GE, Shi Q. A mitocentric view of Alzheimer's disease suggests multi-faceted treatments. J Alzheimers Dis 2010;20(Suppl. 2):S591-S607.

12. Hauptmann S, Scherping I, Drose S, et al. Mitochondrial dysfunction: an early event in Alzheimer pathology accumulates with age in AD transgenic mice. Neurobiol Aging 2009;30:1574-1586.

13. Nicholson RM, Kusne Y, Nowak LA, LaFerla FM, Reiman EM, Valla J. Regional cerebral glucose uptake in the 3xTG model of Alzheimer's disease highlights common regional vulnerability across AD mouse models. Brain Res 2010;1347:179-185.

14. Ishii K, Sasaki M, Kitagaki H, et al. Reduction of cerebellar glucose metabolism in advanced Alzheimers Dis 1997;38:925-928.

15. Mosconi L, De Santi S, Li J, et al. Hippocampal hypometabolism predicts cognitive decline from normal aging. Neurobiol Aging 2008;29:676-692.

16. Protas HD, Chen K, Langbaum JB, et al. Posterior cingulate glucose metabolism, hippocampal glucose metabolism, and hippocampal volume in cognitively normal, late-middle-aged persons at 3 levels of genetic risk for Alzheimer disease. JAMA Neurol 2013;70:320-325.

17. De Santi S, de Leon MJ, Rusinek H, et al. Hippocampal formation glucose metabolism and volume losses in $\mathrm{MCI}$ and $\mathrm{AD}$. Neurobiol Aging 2001;22:529-539.

18. Moreira PI, Carvalho C, Zhu X, Smith MA, Perry G. Mitochondrial dysfunction is a trigger of Alzheimer's disease pathophysiology. Biochim Biophys Acta 2010;1802:2-10.

19. Schmitt K, Grimm A, Kazmierczak A, Strosznajder JB, Gotz J, Eckert A. Insights into mitochondrial dysfunction: aging, amyloidbeta, and tau-A deleterious trio. Antioxid Redox Signal 2012;16: 1456-1466.

20. David DC, Hauptmann S, Scherping I, et al. Proteomic and functional analyses reveal a mitochondrial dysfunction in P301L tau transgenic mice. J Biol Chem 2005;280:23802-23814.

21. Caspersen C, Wang N, Yao J, et al. Mitochondrial Abeta: a potential focal point for neuronal metabolic dysfunction in Alzheimer's disease. FASEB J 2005;19:2040-2041.

22. Eckert A, Schulz KL, Rhein V, Gotz J. Convergence of amyloidbeta and tau pathologies on mitochondria in vivo. Mol Neurobiol 2010;41:107-114.

23. Schon EA, Przedborski S. Mitochondria: the next (neurode)generation. Neuron. 2011;70:1033-1053.

24. Yao J, Irwin RW, Zhao L, Nilsen J, Hamilton RT, Brinton RD. Mitochondrial bioenergetic deficit precedes Alzheimer's pathology in female mouse model of Alzheimer's disease. Proc Natl Acad Sci U S A 2009;106:14670-14675.

25. Du H, Guo L, Yan S, Sosunov AA, McKhann GM, Yan SS. Early deficits in synaptic mitochondria in an Alzheimer's disease mouse model. Proc Natl Acad Sci U S A 2010;107:18670-18675.

26. de Leon MJ, Convit A, Wolf OT, et al. Prediction of cognitive decline in normal elderly subjects with 2-[(18)F]fluoro-2-deoxyD-glucose/poitron-emission tomography (FDG/PET). Proc Natl Acad Sci U S A 2001;98:10966-10971.

27. Mosconi L, Mistur R, Switalski R, et al. FDG-PET changes in brain glucose metabolism from normal cognition to pathologically verified Alzheimers Dis 2009;36:811-822.
28. Reiman EM, Chen K, Alexander GE, et al. Functional brain abnormalities in young adults at genetic risk for late-onset Alzheimer's dementia. Proc Natl Acad Sci U S A 2004;101:284-289.

29. Rosenbloom MH, Alkalay A, Agarwal N, et al. Distinct clinical and metabolic deficits in PCA and AD are not related to amyloid distribution. Neurology 2011;76:1789-1796.

30. Swerdlow RH, Burns JM, Khan SM. The Alzheimer's disease mitochondrial cascade hypothesis: progress and perspectives. Biochim Biophys Acta 2014;1842:1219-1231.

31. Ding F, Yao J, Rettberg JR, Chen S, Brinton RD. Early decline in glucose transport and metabolism precedes shift to ketogenic system in female aging and Alzheimer's mouse brain: implication for bioenergetic intervention. PloS One 2013;8:e79977.

32. Swerdlow RH. Bioenergetic medicine. Br J Pharmacol 2014;171: 1854-1869.

33. Brinton RD. The healthy cell bias of estrogen action: mitochondrial bioenergetics and neurological implications. Trends Neurosci 2008;31:529-537.

34. Cardoso SM, Santana I, Swerdlow RH, Oliveira CR. Mitochondria dysfunction of Alzheimer's disease cybrids enhances Abeta toxicity. J Neurochem 2004;89:1417-1426.

35. Swerdlow RH. Mitochondria in cybrids containing mtDNA from persons with mitochondriopathies. J Neurosci Res 2007;85:34163428.

36. Swerdlow RH, Khan SM. The Alzheimer's disease mitochondrial cascade hypothesis: an update. Exp Neurol 2009;218:308-315.

37. Blass JP, Sheu RK, Gibson GE. Inherent abnormalities in energy metabolism in Alzheimer disease. Interaction with cerebrovascular compromise. Ann N Y Acad Sci 2000;903:204-221.

38. Cardoso SM, Proenca MT, Santos S, Santana I, Oliveira CR. Cytochrome c oxidase is decreased in Alzheimer's disease platelets. Neurobiol Aging 2004;25:105-110.

39. Gibson GE, Sheu KF, Blass JP, et al. Reduced activities of thiaminedependent enzymes in the brains and peripheral tissues of patients with Alzheimer's disease. Arch Neurol 1988;45:836-840.

40. Parker WD, Jr. Cytochrome oxidase deficiency in Alzheimer's disease. Ann N Y Acad Sci 1991;640:59-64.

41. Perry EK, Perry RH, Tomlinson BE, Blessed G, Gibson PH. Coenzyme A-acetylating enzymes in Alzheimer's disease: possible cholinergic 'compartment' of pyruvate dehydrogenase. Neurosci Lett 1980;18:105-110.

42. Sorbi S, Bird ED, Blass JP. Decreased pyruvate dehydrogenase complex activity in Huntington and Alzheimer brain. Ann Neurol 1983;13:72-78.

43. Reiman EM, Brinton RD, Katz R, et al. Considerations in the design of clinical trials for cognitive aging. J Gerontol A Biol Sci Med Sci 2012;67:766-772.

44. Carrillo MC, Brashear HR, Logovinsky V, et al. Can we prevent Alzheimer's disease? Secondary "prevention" trials in Alzheimer's disease. Alzheimers Dement 2013;9:123-131.

45. Chetelat G, Desgranges B, de la Sayette V, Viader F, Eustache F, Baron JC. Mild cognitive impairment: Can FDG-PET predict who is to rapidly convert to Alzheimer's disease? Neurology 2003;60: 1374-1377.

46. Watson GS, Craft S. The role of insulin resistance in the pathogenesis of Alzheimer's disease: implications for treatment. CNS Drugs 2003; 17:27-45.

47. Cholerton B, Baker LD, Craft S. Insulin, cognition, and dementia. Eur J Pharmacol 2013;719:170-179.

48. de la Monte SM. Type 3 diabetes is sporadic Alzheimers disease: Mini-review. Eur Neuropsychopharmacol 2014 Jun 28.

49. de la Monte SM. Relationships between diabetes and cognitive impairment. Endocrinol Metab Clin North Am 2014;43:245-267.

50. Craft S, Baker LD, Montine TJ, et al. Intranasal insulin therapy for Alzheimer disease and amnestic mild cognitive impairment: a pilot clinical trial. Arch Neurol 2012;69:29-38. 
51. Reger MA, Watson GS, Green PS, et al. Intranasal insulin administration dose-dependently modulates verbal memory and plasma amyloid-beta in memory-impaired older adults. J Alzheimers Dis 2008;13:323-331.

52. Gomes MB, Negrato CA, Cobas R, et al. Determinants of intensive insulin therapeutic regimens in patients with type 1 diabetes: data from a nationwide multicenter survey in Brazil. Diabetol Metab Syndr 2014;6:67.

53. Novak V, Milberg W, Hao Y, et al. Enhancement of vasoreactivity and cognition by intranasal insulin in type 2 diabetes. Diabetes Care 2014;37:751-759.

54. Starkova NT, Biriukova EV, Dvoriashina IV, Murakhovskaia EV. [Impaired fat tolerance as a risk factor of insulin resistance in young patients with obesity]. Klin Med (Mosk) 2004;82:42-47 (in Russian).

55. Starkova NT, Dvoriashina IV. [Metabolic syndrome of insulin resistance: basic conception and consequences ( a review)]. Ter Arkh 2004;76:54-58 (in Russian).

56. Kashiwaya Y, Bergman C, Lee JH, et al. A ketone ester diet exhibits anxiolytic and cognition-sparing properties, and lessens amyloid and tau pathologies in a mouse model of Alzheimer's disease. Neurobiol Aging 2013;34:1530-1539.

57. Brownlow ML, Benner L, D'Agostino D, Gordon MN, Morgan D. Ketogenic diet improves motor performance but not cognition in two mouse models of Alzheimer's pathology. PloS One 2013;8: e75713.

58. Reger MA, Henderson ST, Hale C, et al. Effects of betahydroxybutyrate on cognition in memory-impaired adults. Neurobiol Aging 2004;25:311-314.

59. Henderson ST, Vogel JL, Barr LJ, Garvin F, Jones JJ, Costantini LC. Study of the ketogenic agent AC-1202 in mild to moderate Alzheimer's disease: a randomized, double-blind, placebo-controlled, multicenter trial. Nutr Metab (Lond) 2009;6:31.

60. Krikorian R, Shidler MD, Dangelo K, Couch SC, Benoit SC, Clegg DJ. Dietary ketosis enhances memory in mild cognitive impairment. Neurobiol Aging 2012;33:425.

61. Swerdlow R, Marcus DL, Landman J, Harooni M, Freedman ML. Brain glucose and ketone body metabolism in patients with Alzheimer's disease. Clin Res 1989;37:A461.

62. Panov A, Orynbayeva Z, Vavilin V, Lyakhovich V. Fatty acids in energy metabolism of the central nervous system. BioMed Res Int 2014;2014:472459.

63. Magistretti PJ. Neuron-glia metabolic coupling and plasticity. J Exp Biol 2006;209:2304-2311.

64. Owen OE, Morgan AP, Kemp HG, Sullivan JM, Herrera MG, Cahill GF, Jr. Brain metabolism during fasting. J Clin Invest 1967;46:1589-1595.

65. Swerdlow RH. Role and treatment of mitochondrial DNA-related mitochondrial dysfunction in sporadic neurodegenerative diseases. Curr Pharm Des 2011;17:3356-3373.

66. Beckett TL, Studzinski CM, Keller JN, Paul Murphy M, Niedowicz DM. A ketogenic diet improves motor performance but does not affect beta-amyloid levels in a mouse model of Alzheimer's disease. Brain Res 2013;1505:61-67.

67. Swerdlow RH. Mitochondrial medicine and the neurodegenerative mitochondriopathies. Pharmaceuticals (Basel) 2009;2:150-167.

68. Mancuso M, Orsucci D, Volpi L, Calsolaro V, Siciliano G. Coenzyme Q10 in neuromuscular and neurodegenerative disorders. Curr Drug Targets 2010;11:111-121.

69. Bergamasco B, Scarzella L, La Commare P. Idebenone, a new drug in the treatment of cognitive impairment in patients with dementia of the Alzheimer type. Funct Neurol 1994;9:161-168.

70. Gutzmann H, Hadler D. Sustained efficacy and safety of idebenone in the treatment of Alzheimer's disease: update on a 2-year double-blind multicentre study. J Neural Transm Suppl 1998;54:301-310.
71. Weyer G, Babej-Dolle RM, Hadler D, Hofmann S, Herrmann WM. A controlled study of 2 doses of idebenone in the treatment of Alzheimer's disease. Neuropsychobiology 1997;36:73-82.

72. Thal LJ, Grundman M, Berg J, et al. Idebenone treatment fails to slow cognitive decline in Alzheimer's disease. Neurology 2003;61: 1498-1502.

73. Wenz T, Diaz F, Spiegelman BM, Moraes CT. Activation of the PPAR/PGC-1alpha pathway prevents a bioenergetic deficit and effectively improves a mitochondrial myopathy phenotype. Cell Metab 2008;8:249-256.

74. Wenz T, Wang X, Marini M, Moraes CT. A metabolic shift induced by a PPAR panagonist markedly reduces the effects of pathogenic mitochondrial tRNA mutations. J Cell Mol Med 2011;15:23172325.

75. Escribano L, Simon AM, Perez-Mediavilla A, Salazar-Colocho P, Del Rio J, Frechilla D. Rosiglitazone reverses memory decline and hippocampal glucocorticoid receptor down-regulation in an Alzheimer's disease mouse model. Biochem Biophys Res Commun 2009;379:406-410.

76. Nicolakakis N, Aboulkassim T, Ongali B, et al. Complete rescue of cerebrovascular function in aged Alzheimer's disease transgenic mice by antioxidants and pioglitazone, a peroxisome proliferatoractivated receptor gamma agonist. J Neurosci 2008;28:9287-9296.

77. Strum JC, Shehee R, Virley D, et al. Rosiglitazone induces mitochondrial biogenesis in mouse brain. J Alzheimers Dis 2007;11:4551.

78. Ghosh S, Patel N, Rahn D, et al. The thiazolidinedione pioglitazone alters mitochondrial function in human neuron-like cells. Mol Pharmacol 2007;71:1695-1702.

79. Eleff S, Kennaway NG, Buist NR, et al. 31P NMR study of improvement in oxidative phosphorylation by vitamins $\mathrm{K} 3$ and $\mathrm{C}$ in a patient with a defect in electron transport at complex III in skeletal muscle. Proc Natl Acad Sci U S A 1984;81:3529-3533.

80. Callaway NL, Riha PD, Bruchey AK, Munshi Z, Gonzalez-Lima F. Methylene blue improves brain oxidative metabolism and memory retention in rats. Pharmacol Biochem Behav 2004;77:175-181.

81. Atamna H, Nguyen A, Schultz C, et al. Methylene blue delays cellular senescence and enhances key mitochondrial biochemical pathways. FASEB J 2008;22:703-712.

82. Atamna H, Kumar R. Protective role of methylene blue in Alzheimer's disease via mitochondria and cytochrome c oxidase. J Alzheimers Dis 2010;20(Suppl. 2):S439-S452.

83. Dumont M, Beal MF. Neuroprotective strategies involving ROS in Alzheimer disease. Free Radic Biol Med 2011;51:1014-1026.

84. Schoenen J, Jacquy J, Lenaerts M. Effectiveness of high-dose riboflavin in migraine prophylaxis. A randomized controlled trial. Neurology 1998;50:466-470.

85. Dumont M, Lin MT, Beal MF. Mitochondria and antioxidant targeted therapeutic strategies for Alzheimer's disease. J Alzheimers Dis 2010;20(Suppl. 2):S633-S643.

86. Shefner JM, Cudkowicz ME, Schoenfeld D, et al. A clinical trial of creatine in ALS. Neurology 2004;63:1656-1661.

87. Verbessem P, Lemiere J, Eijnde BO, et al. Creatine supplementation in Huntington's disease: a placebo-controlled pilot trial. Neurology 2003;61:925-930.

88. Klivenyi P, Calingasan NY, Starkov A, et al. Neuroprotective mechanisms of creatine occur in the absence of mitochondrial creatine kinase. Neurobiol Dis 2004;15:610-617.

89. Kang D, Kim SH, Hamasaki N. Mitochondrial transcription factor A (TFAM): roles in maintenance of mtDNA and cellular functions. Mitochondrion 2007;7:39-44.

90. Scarpulla RC. Transcriptional paradigms in mammalian mitochondrial biogenesis and function. Physiol Rev 2008;88:611-638.

91. Ekstrand MI, Falkenberg M, Rantanen A, et al. Mitochondrial transcription factor A regulates mtDNA copy number in mammals. Hum Mol Genet 2004;13:935-944. 
92. Hanyu H, Sato T, Kiuchi A, Sakurai H, Iwamoto T. Pioglitazone improved cognition in a pilot study on patients with Alzheimer's disease and mild cognitive impairment with diabetes mellitus. J Am Geriatr Soc 2009;57:177-179.

93. Sato T, Hanyu H, Hirao K, Kanetaka H, Sakurai H, Iwamoto T. Efficacy of PPAR-gamma agonist pioglitazone in mild Alzheimer disease. Neurobiol Aging 2011;32:1626-1633.

94. Watson GS, Cholerton BA, Reger MA, et al. Preserved cognition in patients with early Alzheimer disease and amnestic mild cognitive impairment during treatment with rosiglitazone: a preliminary study. Am J Geriatr Psychiatry 2005;13:950-958.

95. Risner ME, Saunders AM, Altman JF, et al. Efficacy of rosiglitazone in a genetically defined population with mild-to-moderate Alzheimer's disease. Pharmacogenomics J 2006;6:246-254.

96. Khan SM, Bennett JP, Jr. Development of mitochondrial gene replacement therapy. J Bioenerg Biomembr 2004;36:387-393.

97. Pardridge WM. Molecular biology of the blood-brain barrier. Mol Biotechnol 2005;30:57-70.

98. Lin MT, Beal MF. Mitochondrial dysfunction and oxidative stress in neurodegenerative diseases. Nature 2006;443:787-795.

99. Cadenas E. Mitochondrial free radical production and cell signaling. Mol Aspects Med 2004;25:17-26.

100. Yap LP, Garcia JV, Han D, Cadenas E. The energy-redox axis in aging and age-related neurodegeneration. Adv Drug Deliv Rev 2009;61:1283-1298.

101. Kubli DA, Gustafsson AB. Mitochondria and mitophagy: the yin and yang of cell death control. Circ Res 2012;111:1208-1221.

102. Wang X, Wang W, Li L, Perry G, Lee HG, Zhu X. Oxidative stress and mitochondrial dysfunction in Alzheimer's disease. Biochim Biophys Acta 2014;1842:1240-1247.

103. Beal MF. Mitochondria take center stage in aging and neurodegeneration. Ann Neurol 2005;58:495-505.

104. Reddy PH, Beal MF. Amyloid beta, mitochondrial dysfunction and synaptic damage: implications for cognitive decline in aging and Alzheimer's disease. Trends Mol Med 2008;14:45-53.

105. Butterfield DA, Di Domenico F, Barone E. Elevated risk of type 2 diabetes for development of Alzheimer disease: a key role for oxidative stress in brain. Biochim Biophys Acta 2014;1842:16931706.

106. Starkov AA, Fiskum G, Chinopoulos C, et al. Mitochondrial alphaketoglutarate dehydrogenase complex generates reactive oxygen species. J Neurosci 2004;24:7779-7788.

107. Nunomura A, Chiba S, Lippa CF, et al. Neuronal RNA oxidation is a prominent feature of familial Alzheimer's disease. Neurobiol Dis 2004; 17:108-113.

108. Reddy PH. Mitochondrial oxidative damage in aging and Alzheimer's disease: implications for mitochondrially targeted antioxidant therapeutics. J Biomed Biotechnol 2006;2006:31372.

109. Zhang Y, Schuff N, Jahng GH, et al. Diffusion tensor imaging of cingulum fibers in mild cognitive impairment and Alzheimer disease. Neurology 2007;68:13-19.

110. Zhao L, Brinton RD. WHI and WHIMS follow-up and human studies of soy isoflavones on cognition. Exp Rev Neurother 2007;7:1549-1564.

111. Lopes da Silva S, Vellas B, Elemans S, et al. Plasma nutrient status of patients with Alzheimer's disease: Systematic review and metaanalysis. Alzheimers Dement 2014;10:485-502.

112. Mi W, van Wijk N, Cansev M, Sijben JW, Kamphuis PJ. Nutritional approaches in the risk reduction and management of Alzheimer's disease. Nutrition 2013;29:1080-1089.

113. Shah R. The role of nutrition and diet in Alzheimer disease: a systematic review. J Am Med Dir Assoc 2013;14:398-402.

114. Bjelakovic G, Nikolova D, Gluud LL, Simonetti RG, Gluud C. Mortality in randomized trials of antioxidant supplements for primary and secondary prevention: systematic review and meta-analysis. JAMA 2007;297:842-857.
115. Harrison FE, Allard J, Bixler R, et al. Antioxidants and cognitive training interact to affect oxidative stress and memory in APP/ PSEN1 mice. Nutr Neurosci 2009;12:203-218.

116. Sung S, Yao Y, Uryu K, et al. Early vitamin E supplementation in young but not aged mice reduces Abeta levels and amyloid deposition in a transgenic model of Alzheimer's disease. FASEB J 2004;18:323-325.

117. Jack CR, Jr., Petersen RC, Grundman M, et al. Longitudinal MRI findings from the vitamin $\mathrm{E}$ and donepezil treatment study for MCI. Neurobiol Aging 2008;29:1285-1295.

118. Parnetti L, Ambrosoli L, Abate G, et al. Posatirelin for the treatment of late-onset Alzheimer's disease: a double-blind multicentre study vs citicoline and ascorbic acid. Acta Neurol Scand 1995;92:135-140.

119. Sano M, Ernesto C, Thomas RG, et al. A controlled trial of selegiline, alpha-tocopherol, or both as treatment for Alzheimer's disease. The Alzheimer's Disease Cooperative Study. N Engl J Med 1997;336:1216-1222.

120. Dysken MW, Sano M, Asthana S, et al. Effect of vitamin E and memantine on functional decline in Alzheimer disease: the TEAMAD VA cooperative randomized trial. JAMA 2014;311:33-44.

121. Hardeland R. Antioxidative protection by melatonin: multiplicity of mechanisms from radical detoxification to radical avoidance. Endocrine 2005;27:119-130.

122. Larson J, Jessen RE, Uz T, et al. Impaired hippocampal long-term potentiation in melatonin MT2 receptor-deficient mice. Neurosci Lett 2006;393:23-26.

123. Feng Z, Qin C, Chang Y, Zhang JT. Early melatonin supplementation alleviates oxidative stress in a transgenic mouse model of Alzheimer's disease. Free Radic Biol Med 2006;40:101-109.

124. Olcese JM, Cao C, Mori T, et al. Protection against cognitive deficits and markers of neurodegeneration by long-term oral administration of melatonin in a transgenic model of Alzheimer disease. J Pineal Res 2009;47:82-96.

125. Lim GP, Chu T, Yang F, Beech W, Frautschy SA, Cole GM. The curry spice curcumin reduces oxidative damage and amyloid pathology in an Alzheimer transgenic mouse. J Neurosci 2001;21: 8370-8377.

126. Yang F, Lim GP, Begum AN, et al. Curcumin inhibits formation of amyloid beta oligomers and fibrils, binds plaques, and reduces amyloid in vivo. J Biol Chem 2005;280:5892-5901.

127. Garcia-Alloza M, Borrelli LA, Rozkalne A, Hyman BT, Bacskai BJ. Curcumin labels amyloid pathology in vivo, disrupts existing plaques, and partially restores distorted neurites in an Alzheimer mouse model. J Neurochem 2007;102:1095-1104.

128. Zhang L, Fiala M, Cashman J, et al. Curcuminoids enhance amyloid-beta uptake by macrophages of Alzheimer's disease patients. J Alzheimers Dis 2006;10:1-7.

129. Grodstein F, Chen J, Willett WC. High-dose antioxidant supplements and cognitive function in community-dwelling elderly women. Am J Clin Nutr 2003;77:975-984.

130. Morris MC, Evans DA, Bienias JL, et al. Dietary intake of antioxidant nutrients and the risk of incident Alzheimer disease in a biracial community study. JAMA 2002;287:3230-3237.

131. McManus MJ, Murphy MP, Franklin JL. The mitochondria-targeted antioxidant MitoQ prevents loss of spatial memory retention and early neuropathology in a transgenic mouse model of Alzheimer's disease. J Neurosci 2011;31:15703-15715.

132. Karuppagounder SS, Pinto JT, Xu H, Chen HL, Beal MF, Gibson GE. Dietary supplementation with resveratrol reduces plaque pathology in a transgenic model of Alzheimer's disease. Neurochem Int 2009;54:111-118.

133. Vingtdeux V, Giliberto L, Zhao H, et al. AMP-activated protein kinase signaling activation by resveratrol modulates amyloid-beta peptide metabolism. J Biol Chem 2010;285:9100-9113.

134. Beher D, Wu J, Cumine S, et al. Resveratrol is not a direct activator of SIRT1 enzyme activity. Chem Biol Drug Des 2009;74:619-624. 
135. Canto C, Gerhart-Hines Z, Feige JN, et al. AMPK regulates energy expenditure by modulating NAD + metabolism and SIRT1 activity. Nature 2009;458:1056-1060.

136. Canto C, Jiang LQ, Deshmukh AS, et al. Interdependence of AMPK and SIRT1 for metabolic adaptation to fasting and exercise in skeletal muscle. Cell Metab 2010;11:213-219.

137. Um JH, Park SJ, Kang H, et al. AMP-activated protein kinasedeficient mice are resistant to the metabolic effects of resveratrol. Diabetes 2010;59:554-563.

138. Baur JA, Pearson KJ, Price NL, et al. Resveratrol improves health and survival of mice on a high-calorie diet. Nature 2006;444:337342.

139. Timmers S, Konings E, Bilet L, et al. Calorie restriction-like effects of 30 days of resveratrol supplementation on energy metabolism and metabolic profile in obese humans. Cell Metab 2011;14:612622

140. Shigenaga MK, Hagen TM, Ames BN. Oxidative damage and mitochondrial decay in aging. Proc Natl Acad Sci U S A 1994;91: 10771-10778.

141. Shoulson I. DATATOP: a decade of neuroprotective inquiry. Parkinson Study Group. Deprenyl and tocopherol antioxidative therapy of Parkinsonism. Ann Neurol 1998;44(3 Suppl. 1):S160 S166.

142. Miller ER, 3rd, Pastor-Barriuso R, Dalal D, Riemersma RA, Appel LJ, Guallar E. Meta-analysis: high-dosage vitamin E supplementation may increase all-cause mortality. Ann Intern Med 2005;142: $37-46$.

143. Gottlieb RA, Carreira RS. Autophagy in health and disease. 5. Mitophagy as a way of life. Am J Physiol Cell Physiol 2010;299: C203-C210

144. Vosler PS, Graham SH, Wechsler LR, Chen J. Mitochondrial targets for stroke: focusing basic science research toward development of clinically translatable therapeutics. Stroke 2009;40:3149-3155.

145. Bachurin SO, Shevtsova EP, Kireeva EG, Oxenkrug GF, Sablin SO. Mitochondria as a target for neurotoxins and neuroprotective agents. Ann N Y Acad Sci 2003;993:334-344.

146. Andreux PA, Houtkooper RH, Auwerx J. Pharmacological approaches to restore mitochondrial function. Nat Rev Drug Discov 2013; 12:465-483.

147. Chen H, Chan DC. Mitochondrial dynamics-fusion, fission, movement, and mitophagy - in neurodegenerative diseases. Hum Mol Genet 2009;18:R169-R176.

148. Harrison DE, Strong R, Sharp ZD, et al. Rapamycin fed late in life extends lifespan in genetically heterogeneous mice. Nature 2009;460:392-395.

149. Jung CH, Ro SH, Cao J, Otto NM, Kim DH. mTOR regulation of autophagy. FEBS Lett 2010;584:1287-1295.

150. Kapahi P, Chen D, Rogers AN, et al. With TOR, less is more: a key role for the conserved nutrient-sensing TOR pathway in aging. Cell Metab 2010;11:453-465.

151. Spilman P, Podlutskaya N, Hart MJ, et al. Inhibition of mTOR by rapamycin abolishes cognitive deficits and reduces amyloid-beta levels in a mouse model of Alzheimer's disease. PloS One 2010;5: e9979.

152. Zhang S, Hedskog L, Petersen CA, Winblad B, Ankarcrona M. Dimebon (latrepirdine) enhances mitochondrial function and protects neuronal cells from death. J Alzheimers Dis 2010;21:389-402.

153. Grigorev VV, Dranyi OA, Bachurin SO. Comparative study of action mechanisms of dimebon and memantine on AMPA- and NMDA-subtypes glutamate receptors in rat cerebral neurons. Bull Exp Biol Med 2003;136:474-477.

154. Lermontova NN, Redkozubov AE, Shevtsova EF, Serkova TP, Kireeva EG, Bachurin SO. Dimebon and tacrine inhibit neurotoxic action of beta-amyloid in culture and block L-type $\mathrm{Ca}(2+)$ channels. Bull Exp Biol Med 2001;132:1079-1083.
155. Doody RS, Gavrilova SI, Sano M, et al. Effect of dimebon on cognition, activities of daily living, behaviour, and global function in patients with mild-to-moderate Alzheimer's disease: a randomised, double-blind, placebo-controlled study. Lancet 2008;372:207-215.

156. Bezprozvanny I. The rise and fall of Dimebon. Drug News Perspect 2010;23:518-523.

157. Miller G. Pharmacology. The puzzling rise and fall of a dark-horse Alzheimer's drug. Science 2010;327:1309.

158. Kanninen K, Malm TM, Jyrkkanen HK, et al. Nuclear factor erythroid 2-related factor 2 protects against beta amyloid. Mol Cell Neurosci 2008;39:302-313.

159. Kanninen K, Heikkinen R, Malm T, et al. Intrahippocampal injection of a lentiviral vector expressing Nrf2 improves spatial learning in a mouse model of Alzheimer's disease. Proc Natl Acad Sci U S A 2009;106:16505-16510.

160. Liby K, Hock T, Yore MM, et al. The synthetic triterpenoids, CDDO and CDDO-imidazolide, are potent inducers of heme oxygenase-1 and Nrf2/ARE signaling. Cancer Res 2005;65: 4789-4798.

161. Liby KT, Yore MM, Sporn MB. Triterpenoids and rexinoids as multifunctional agents for the prevention and treatment of cancer. Nat Rev Cancer 2007;7:357-369.

162. Mattson MP. Energy intake and exercise as determinants of brain health and vulnerability to injury and disease. Cell Metabol 2012;16:706-722

163. Johnson JB, Summer W, Cutler RG, et al. Alternate day calorie restriction improves clinical findings and reduces markers of oxidative stress and inflammation in overweight adults with moderate asthma. Free Radic Biol Med 2007;42:665-674.

164. Redman LM, Ravussin E. Caloric restriction in humans: impact on physiological, psychological, and behavioral outcomes. Antioxid Redox Signal 2011;14:275-287.

165. Weiss EP, Fontana L. Caloric restriction: powerful protection for the aging heart and vasculature. Am J Physiol Heart Circ Physiol 2011;301:H1205-H1219.

166. Wallace DC. A mitochondrial paradigm of metabolic and degenerative diseases, aging, and cancer: a dawn for evolutionary medicine. Annu Rev Genet 2005;39:359-407.

167. Lezi E, Lu J, Burns JM, Swerdlow RH. Effect of exercise on mouse liver and brain bioenergetic infrastructures. Exp Physiol 2013;98: 207-219.

168. Lezi E, Lu J, Selfridge JE, Burns JM, Swerdlow RH. Lactate administration reproduces specific brain and liver exercise-related changes. J Neurochem 2013;127:91-100.

169. van Praag H, Shubert T, Zhao C, Gage FH. Exercise enhances learning and hippocampal neurogenesis in aged mice. J Neurosci 2005;25:8680-8685.

170. Cotman CW, Berchtold NC. Exercise: a behavioral intervention to enhance brain health and plasticity. Trends Neurosci 2002;25:295301.

171. Navarro A, Gomez C, Lopez-Cepero JM, Boveris A. Beneficial effects of moderate exercise on mice aging: survival, behavior, oxidative stress, and mitochondrial electron transfer. Am J Physiol Regul Integr Comp Physiol 2004;286:R505-R511.

172. Steiner JL, Murphy EA, McClellan JL, Carmichael MD, Davis JM. Exercise training increases mitochondrial biogenesis in the brain. $\mathrm{J}$ Appl Physiol 2011;111:1066-1071.

173. Willett WC, Sacks F, Trichopoulou A, et al. Mediterranean diet pyramid: a cultural model for healthy eating. Am J Clin Nutr 1995;61(6 Suppl.):1402S-1406S.

174. Bach-Faig A, Berry EM, Lairon D, et al. Mediterranean diet pyramid today. Science and cultural updates. Public Health Nutr 2011;14:2274-2284.

175. Alles B, Samieri C, Feart C, Jutand MA, Laurin D, BarbergerGateau P. Dietary patterns: a novel approach to examine the link 
between nutrition and cognitive function in older individuals. Nutr Res Rev 2012;25:207-222.

176. Serra-Majem L, Roman B, Estruch R. Scientific evidence of interventions using the Mediterranean diet: a systematic review. Nutr Rev 2006;64:S27-S47.

177. Sofi F, Abbate R, Gensini GF, Casini A. Accruing evidence on benefits of adherence to the Mediterranean diet on health: an updated systematic review and meta-analysis. Am J Clin Nutr 2010;92:1189-1196.

178. Gaskins AJ, Rovner AJ, Mumford SL, et al. Adherence to a Mediterranean diet and plasma concentrations of lipid peroxidation in premenopausal women. Am J Clin Nutr 2010;92:1461-1467.

179. Dai J, Jones DP, Goldberg J, et al. Association between adherence to the Mediterranean diet and oxidative stress. Am J Clin Nutr 2008;88:1364-1370.

180. Giugliano D, Esposito K. Mediterranean diet and metabolic diseases. Curr Opin Lipidol 2008;19:63-68.

181. Feart C, Alles B, Merle B, Samieri C, Barberger-Gateau P. Adherence to a Mediterranean diet and energy, macro-, and micronutrient intakes in older persons. J Physiol Biochem 2012;68:691-700.

182. Rettberg JR, Yao J, Brinton RD. Estrogen: a master regulator of bioenergetic systems in the brain and body. Front Neuroendocrinol 2014;35:8-30.

183. Dixon RA. Phytoestrogens. Annu Rev Plant Biol 2004;55:225-261.

184. Hammond CB. Women's concerns with hormone replacement therapy-compliance issues. Fertil Steril 1994;62(6 Suppl. 2):157S$160 \mathrm{~S}$.

185. Setchell KD. Phytoestrogens: the biochemistry, physiology, and implications for human health of soy isoflavones. Am J Clin Nutr 1998;68(6 Suppl.):1333S-1346S.

186. Yao J, Zhao L, Mao Z, et al. Potentiation of brain mitochondrial function by $\mathrm{S}$-equol and R/S-equol estrogen receptor beta-selective phytoSERM treatments. Brain Res 2013;1514:128-141.

187. Shi J, Simpkins JW. 17 beta-Estradiol modulation of glucose transporter 1 expression in blood-brain barrier. Am J Physiol 1997;272(6 Pt 1):E1016-E1022.
188. Kostanyan A, Nazaryan K. Rat brain glycolysis regulation by estradiol-17 beta. Biochim Biophys Acta 1992;1133:301-306.

189. Diaz Brinton R. Minireview: translational animal models of human menopause: challenges and emerging opportunities. Endocrinology 2012;153:3571-3578

190. Adlard PA, Cherny RA, Finkelstein DI, et al. Rapid restoration of cognition in Alzheimer's transgenic mice with 8-hydroxy quinoline analogs is associated with decreased interstitial Abeta. Neuron 2008;59:43-55.

191. Lannfelt L, Blennow K, Zetterberg H, et al. Safety, efficacy, and biomarker findings of PBT2 in targeting Abeta as a modifying therapy for Alzheimer's disease: a phase IIa, double-blind, randomised, placebo-controlled trial. Lancet Neurol 2008;7:779 786.

192. Ritchie CW, Bush AI, Mackinnon A, et al. Metal-protein attenuation with iodochlorhydroxyquin (clioquinol) targeting Abeta amyloid deposition and toxicity in Alzheimer disease: a pilot phase 2 clinical trial. Arch Neurol 2003;60:1685-1691.

193. Scheltens P, Twisk JW, Blesa R, et al. Efficacy of Souvenaid in mild Alzheimer's disease: results from a randomized, controlled trial. J Alzheimers Dis 2012;31:225-236.

194. Harvie MN, Pegington M, Mattson MP, et al. The effects of intermittent or continuous energy restriction on weight loss and metabolic disease risk markers: a randomized trial in young overweight women. Int J Obesity 2011;35:714-727.

195. Keys A, Menotti A, Karvonen MJ, et al. The diet and 15-year death rate in the seven countries study. Am J Epidemiol 1986;124:903915.

196. Feart C, Samieri C, Alles B, Barberger-Gateau P. Potential benefits of adherence to the Mediterranean diet on cognitive health. Proc Nutr Soc 2013;72:140-152.

197. Jacobs DR, Jr., Gross MD, Tapsell LC. Food synergy: an operational concept for understanding nutrition. Am J Clin Nutr 2009;89: 1543S-1548S.

198. Kalra EK. Nutraceutical - definition and introduction. AAPS PharmSci. 2003;5:E25. 